\title{
Swearing In Bengkulu-Malay Language In Banter Prespective
}

\author{
Eli Rustinar \\ \{elirustinar@umb.ac.id\} \\ Universitas Muhammadiyah Bengkulu Bengkulu, Indonesia
}

\begin{abstract}
Swearing are generally prohibited from being used freely in the public because the negative nature of swearing is to attack (defensive) by using abusive words, mencarut (the obscene words or has the pornographic meanings), curse, and swear so that it is not liked to be used in daily life. In its realization, swear also has a positive nature with the aim of friendship, intimacy, and affection used in joking or banter as a way to offend to be friendly and based on the study of structure, it also has a marker. Based on this, the purpose of this study was to describe the form of banter that made in Bengkulu -Malay Language. The research method was qualitative with a distributional study method. The data was a swear of the Bengkulu-Malay language with the source of the data was taken from the field research informants. Data collection methods and techniques were carried out through the listening and introspection methods. The method of listening used the basic techniques of tapping techniques which were described in the advanced techniques, namely: (1) Competent free-engage listening techniques (SBLC); (2) Record technique; and (3) Note taking technique. Methods and data analysis techniques used the methods, namely: (1). Contextual analysis methods and (2). The Agih method or the distribution method. The result showed that there were 10 swear used in the context of banter. The form of swear tended to be used the clause form with the using of the second singular pronoun kau 'engkau/kamu' (you) that based on the social distance has indicators of the same degree of familiarity, status or position, and age.The swear data as below: (1) bundung 'the disease of neck swelling in cattle, (2) buyan 'stupid', (3) cuk bak kau 'your fucking father is having sex', (4) palak kau 'your fucking damn head', (5) keparat sgalo toboko 'you're all fucking infidel', (6) ikan buntal 'puffer fish', (7) dasar banci 'you are fucking sissy', (8) palak bak kau 'your father fucking head', (9) tino bunting 'pregnant woman', (10) matilah cepek kau 'you will die soon'.
\end{abstract}

Keywords - Bengkulu-Malay Language, banter, swear

\section{Introduction}

Language society is as a group of people who interact with the mediation of the language using the same sign language system in order to express the various feelings experienced by speakers to foster cooperation between people, but there are times when humans disagree. In 
situations of disagreement, there are speakers who use swear to express displeasure with something that has happened.

Expression of displeasure in swearing is formed when someone reacts due to a trigger factor from outside himself so that the emotional change occurs. Sometimes the emotions felt by a speaker are expressed in an excessive way so that it is brought up spontaneously because they cannot control their emotions. This has an impact on the clearer the intention of swear is understood by everyone, the higher the level of the emotions of the speakers and their effects. And conversely, when the vague meanings of swear are understood by others, the lower the level of emotion and theconsequences that will be happened as the result.

Swear in the online version of The Dictionary of Bahasa Indonesia is derived from the word maki (swear) that also has a more detailed explanation as:

${ }^{1 .}$ swear /swer/ verb, that is: expressing the cruel (dirty, rude, etc.) words (speech) as an outlet for anger or annoyance and so on; 2.swearing /swering/ verb : speak the cruel and inappropriate words, the lackness of custom to express anger or annoyance; 3. the swear words /de swer werds/ noun : the cruel words that are spoken because of the anger and so on). 1.maki /ma ki/ v yaitu: mengeluarkan kata-kata (ucapan) keji (kotor, kasar, dan sebagainya) sebagai pelampiasan kemarahan atau rasa jengkel dan sebagainya; 2. memaki /me·ma·ki/ v mengucapkan kata-kata keji, tidak pantas, kurang adat untuk menyatakan kemarahan atau kejengkelan; 3.makian /ma·ki an/ n kata keji yang diucapkan karena marah dan sebagainya.

Wahya et al. (2018:298) stated that swearing is an indicator of people who say it is in a state of anger and swearing is an expression to be an indicator of the existence of certain emotions. Emotions are feelings that are deeper, broader, conditions that are moved with in the individual that deviates from the normal and calm state. When a person is emotional, various physiological changes will occur in his body, in addition to the changes that occur on the outside of the body and facial expressions.

This shows that there are 2 indicators referred to as swearing, namely: (1). Spoken with anger and others; (2). Have certain emotional symptoms. This concept as explained further, is a symptom of emotions felt by a person can be known through two ways, namely: (1). Verbal expression and (2). Nonverbal expression. Facial expressions, visible bodily symptoms, gestures, facial expressions, and physical changes in the body are signals of nonverbal symptoms that reflect emotions of a person shown by facial expression and hand movements. Whereas the words with emotions underlying the appearance of swear make the expressions shown by language activities, namely: anger, resentment, hatred, and disappointment are verbal expressions.

Verbal expression as a swear according to [1], is a dirty word (profanity) or rude words. Based on this concept, it can be concluded that swear originate from utterances that indeed its function as swearing because they have abusive or dirty words and in Bengkulu-Malay Language, for example, are bangsat (bastards). In addition to rude words, swear can also be the expressions of obscene emotions. Expression of obscenity according to Ullman (2012:261), is an obscene or pornographic word or in Bengkulu-Malay language is called its concept as ncarut with the example is cukimak 'mother's copulation', gendek 'copulation'. Moreover, swear also as referred to by Vingerhoets [2] as a swear, that is to curse someone in the hope of distress or disaster is spoken in the form of prayers to be happened to the hearer and in the BengkuluMalay language is called ngutuk 'cursing' with the example of matilah kau 'you (will) die.'

Based on the existing theories about swear, it can be synthesized that swearing in BengkuluMalay language is a rude or dirty word or it can be mentioned as a swear after its form is in the context that accompanies it in an utterance with the aim of swearing. The associative meaning 
contained in the context makes the utterances become swearing. This context is all of the background knowledge that is understood together between the speaker and the hearer to be able to make an interpretation of what is meant by the speaker when they make certain utterances. This context according to Djajasudarma [3] is formed by various elements which are referred to as components of events. The presence of the speech event component in each utterance makes the intentions captured from the speech event appropriate. The component of this event by Leech [4] is abbreviated as SPEAKING.

The use of swear is often used as a mean of expressing anger, resentment, disappointment, regret, and humiliation, but according to Wijana and Rohmadi [5] in some cultures, swearing is also used in the nuances of intimacy. In such of a context, swear is used to express and create an atmosphere of familiar conversation and is used to create or show intimacy.

The use of swear with the positive intention according to the theory of Leech [4] is referred to as a banter or a joke, that is a way to offend the feeling of hospitality (mock-impoliteness) with an implicature that is contrary to the implication of politeness.

The implication of politeness [4] consists of six politeness maxims as politeness principles in the form of a formula that containing commands (which must be done) or prohibitions (which must not be done or must be avoided). Where as swear has a principle hence it can be stated as follows: "To show solidarity with $t$, say something to $t$ which: (i) is clearly untrue, and (ii) clearly not polite".

The concept of banter can be further explained that banter is often manifested in the casual conversation, especially among the young people (teenagers). For example, in a chess game, one player told the other players in response to a good move: "Кати betul-betul memakai jebakan yang licik" (You really use a cunning trap) or "Ini dia, si pembawa celaka datang" (Here it is , the wretch is coming).

The social phenomena based on the theory of Holmes [6] stated that the way we talk and the contents of conversation of someone can provide clues about us, both of our origin, and our social level, with the reason that the same message can be stated very differently from different people.

According to Holmes [6], there are social factors that influence the use of language toward the person. These social factors include age, gender, and social status. The aspect of social identity of a person can be known from the way someone talks and we do not talk the same way to everyone all the time. The context shows that the way someone talks is a good indicator of their social background.

Familiarity is a social factor that has a special phenomenon. The absence or the reduction of a social distance allows speakers to speak impolitely. Explanation of the social distance scale (Leech distance scale) proposed by Leech [4], is that the degree of respect that exists in a particular word situation largely depends on several factors that are relatively permanent, the factors are status or position, age, degree of familiarity, and so on. This shows that a speech of a person is also more or less dependent on temporary role of a person in relation to others.

The opinion expressed above refer to the ranking of the social relations between the speakers and the hearers involved in a conversation. According to Leech [4] there is a low value on the scale of power and social distance. The concept that as explained further is that if the relationship gets closer, the need for politeness decreases. There is a tendency that the closer the social rank between the two people shows the distance the social rank between the speaker and the hearer so that the more polite utterances are used.

Wijana and Rohmadi [5] stated that, in some cultures, swearing is also used to create a friendly atmosphere of conversation. In this context, swear is used to express and create a 
friendly atmosphere to show intimacy. Rosidin [7] also stated that one of swear identities in certain contexts can be used as a marker of intimacy.

In the findings of research conducted showed that in addition to have a negative function (anger, resentment, hatred), swear also has a positive function (admiration, intimacy, excitement). The swear of this positive function is referred to as a banter. The function of expressing intimacy in swearing is intended to express the closeness of the relationship between the speakers and the hearers so that sometimes it sounds humorous. The examples are as follows:

$$
\begin{aligned}
& \text { O1: 'Astaghfirullah, kurang asem sampeyan iku Mbak' } \\
& \text { Astaghfirullah, Anda itu kurang asem Mbak } \\
& \text { 'Astaghfirullah, you are less acid Ma'am'. }
\end{aligned}
$$

Context: The utterances above showed the use of swear to express intimacy. The unpleasant smell around him was the smell of Lapindo mud that was exposed to the wind, $\mathrm{O} 2$ deliberately accused $\mathrm{O} 1$ of producing farts. Initially $\mathrm{O} 1$ was a bit surprised because she did not feel farting. When $\mathrm{O} 1$ realized that $\mathrm{O} 2$ was just mocking at her and knew that the unpleasant odor was the smell of mud, O1 delivered the swear in the form of less acidic phrases directed at $\mathrm{O} 2$. The swear used by the $\mathrm{O} 1$ did not make the $\mathrm{O} 2$ angry because the utterance addressed to the $\mathrm{O} 2$ is familiar because of the context of the utterance that occurred was banter.

The examples of other swear with the familiarity functions are as follows:

O1: "Suetil koen layangane wernone isok ganti-ganti, wapik Pek, nggatheli?"

Bagus sekali, warna layang-layangnya bisa berubah-ubah, indah sekali Pak, nggateli membuatnya bagaimana ya?'

'Very exquisite, the color of the kite can change, it is damn beautiful Sir, how can you make it, huh?'

Context: Nggatheli' is a penile feces' is a reference to the sexual activity that used by $\mathrm{O} 1$ participant to express admiration at seeing around the tube shaped kite because when it was flying over, it could rotate and changed its colors, in the point that $\mathrm{O} 1$ participant was surprised on how to make a kite flying like that.

Based on the findings and the statements in previous studies, it is also strengthened by the theory of Ljung which stated that, not all swear words have negative intentions [1]. The use of swear may have the intention of friendship, intimacy, and affection. Then swear with positive intentions are referred to in the theory of Leech as a banter or a joke, that is a way to offend to be friendly (mock-impoliteness) [4]. The implication of banter or joke is contrary to the politeness implicature, which is:

"To show solidarity with $t$, say something to $t$ which: (i) is clearly untrue, and (ii) clearly not polite".

Based on this, then in this study, the researcher wanted to know the form of swear in the context of banter in the Bengkulu-Malay language. Because in its realization, it showed that familiarity is a marker factor for the use of swear with that goal that based on the social distance has its indicators of the same degree of familiarity, status or position, and the same age. The absence or the reduction of social distance allows participants to speak impolitely. The closer the distance of relationship of a person, there is a tendency to be impolite of the language used and based on Bengkulu-Malay language, the swear data showed that there was a banter that has a swear mark itself. 


\section{Methods}

The research method was qualitative. The source of data came from the library references, the research results, and the field data. The data was a curse of the Bengkulu-Malay language. Data sources were the speakers and Bengkulu-Malay informants whose numbers were not determined but fulfilled the requirements for adequacy. Data collection methods and techniques were carried out through the listening and introspection methods. The method of listening used the basic techniques of tapping techniques that were described in advanced techniques, namely the ability to engage in competent free listening (SBLC), record techniques, and note techniques. Stages of providing data through three activities, they were: collecting, selecting, and structuring. Analytical methods and techniques used methods that could be called as the contextual analysis method, the method of equivalent study, and the method of distribution.

The method of listening was used to provide data on the use of swear in Bengkulu-Malay Language by using the basic techniques of tapping techniques which were described in advanced techniques, such as: (1). The technique of engagement in competent free listening (SBLC); (2). The record technique; and (3). The note taking technique. The tapping technique was done by tapping the language use by someone without the involvement of the researchers by using a recording tool that was useful for getting data in the actual situations in a complete context. In the next activity, the tapping technique was followed by an advanced technique, namely a competent free listening technique (SBLC). This technique meant that researchers only acted as observers of the use of language by the informants. The researcher was not involved at all in the conversation of the language under the study. The researcher only listened to the dialogue that took place between the participants.

Then, the note taking technique was a follow-up technique that was useful to note the things that were relevant to each participant or the speech events in context to get a more complete picture. The note taking technique was carried out on the data card that had been provided by the researcher, then it was proceeded by classifying or grouping.

The introspection method was used to produce linguistic decisions originating from the native speakers, who have the linguistic competence of the target language in order to check the validity of informant data, and if there was a doubtful data, it would be quickly identified based on the language intuition that the researcher has. The used of introspection methods in this case was an advantage of researching the mother tongue because it could rely on linguistic intuition to the maximum level. The researchers were immediately able to create language data so that the data limitations could be overcome. The doubtful data would be quickly recognized based on the intuition of linguistic researchers. Using the introspection method was useful for creating sentences by providing the context.

Stages of providing data were done through three activities, namely collecting, selecting, and structuring. In the activity of collecting, data was marked by recording, the activity of selecting,could be done by sorting, discarding or removing what was 'followed' which was collected but apparently not necessary, and the structuring activities was to set the type or kind of what utterance that had been recorded, selected, and sorted.

Methods and analysis techniques were done by using three methods, namely: (1). Contextual analysis method; (2). Method of equivalent study; and (3). The Agih method or the distribution method. Contextual is meant relating to the references that discussed the relationship between words, intentions, and the real world by searching for the essence of the intention by describing it. The distribution method was used to analyze the swear form in Bengkulu-Malay language, which was an analysis using the determinant of the language element itself. Both of these concepts have the same way of working, that is the deciding basis 
in the distribution method was the technique of selecting data based on certain categories (criteria) in terms of programmaticity in accordance with the natural characteristics of the research data. The starting point of study started from the data that had been sorted. Sorting was also carried out through language intuition that was already owned by the researchers by dividing the lingual unit of data into several parts or elements; and the elements concerned were seen as a part that directly formed the lingual unit that was meant by the device (the tool for the researcher) was lingual intuition or linguistic intuition.

The two stages of data analysis activities that were called as classifying and grouping data, were carried out with the following activity steps: (1). Classify, describe, and explain the purpose of swear utterance based on the context of the utterance, and (2). Identify the forms and social factors of swearing in Bengkulu-Malay Language. These activities of analysis the swear in Bengkulu-Malay Language were done through some stages that were analysis of the swear form that was done by determining the form of the swear used by the speaker. After the swear form was found, it was continued with an analysis based on age, sex, and social status of the speaker. Examples of data analysis that were contained in swear data as below:

O1:"'Pai kau babi dari siko".

Kau babi pergi dari sini

'You fucking pig out of here!'.

Swear conversations were narrated based on the event components, namely: participant $\mathrm{O} 1$ was the speaker (participant who delivered the swear) while participant O2 was the hearer (participant who was as the swear target). The relationship between participants was close friends and the school peers in junior high school. O1 participant was a boy with a range of 13 years of age and $\mathrm{O} 2$ participant was a boy with a range of 11 years. The 'pig' swear was spoken by participant $\mathrm{O} 1$. The context of the event occurred when the participant $\mathrm{O} 1$ played a game at the internet cafe but it was full so he sat in the corner of the entrance waiting for someone to finish playing. $\mathrm{O} 2$ participant also sat waiting for the others to finish playing. O1 participant took out a cigarette from a shirt pocket while seeing if someone has already finished. O1 participant did not like being seen by $\mathrm{O} 2$ participant. The narrative of the conversation that had been compiled was then continued with an analysis of the forms of swear and the social factors of the swearer,that was called as: (1). The form of the swear. The 'pig' as a swear was spoken by the participant $\mathrm{O} 1$ was a basic noun form of the noun category. (2). The social variables of the hearer (the swear target) were seen based on participant who used 'pig' as a swear word that was used by young participants (teenagers), boy vs. boy. They were as educated junior high school students, the closeness of social distance between participants wass close or it could be seen as close friends or peers.

\section{Result and Discussion}

The researcher could find 10 swear data with the context of banter in Bengkulu-Malay Language, they were: (1) bundung 'the disease of neck swelling in cattle', (2) buyan 'stupid', (3) cuk bak kau 'your fucking father is having sex', (4) palak kau 'your fucking damn head', (5) keparat sgalo toboko 'you're all fucking infidel', (6) ikan buntal 'puffer fish', (7) dasar banci 'you are fucking sissy', (8) palak bak kau 'your father fucking head', (9)tino bunting 'pregnant woman, (10) matilah cepek kau 'you will die soon'. The entire of swear data was in the following table 1 : 
Table 1 Swear with The Banter Context In Bengkulu-Malay Language

\begin{tabular}{ccc}
\hline No & Swear Data & Meaning \\
\hline 1 & (1) bundung & the disease of neck swelling in cattle \\
2 & (2) buyan & Stupid \\
3 & (3) cuk bak kau & your fucking father is having sex \\
4 & (4) palak kau & your fucking damn head \\
5 & (5) keparat sgalo toboko & you're all fucking infidel \\
6 & (6) ikan buntal & puffer fish \\
7 & (7) dasar banci & you are fucking sissy \\
8 & (8) palak bak kau & your father fucking head \\
9 & (9) tino bunting & pregnant woman \\
10 & (10) matilah cepek kau & you will die soon \\
\hline
\end{tabular}

In the society, swear are forbidden to be used freely in the public because the nature of swear was offensive. Swear was negative words that violate the principle of politeness, even though the realization of politeness in language shows that the swear language that is being spoken can also be a banter or a joke or in Bengkulu-Malay language is referred to as mockery. This joke or banter is a way to offend to be friendly (mock-impoliteness). The banter principle is the least important in communication principle, but it is manifested in casual conversation, especially among young people (teenagers).

Based on the unit elements, swear in the context of banter have 2 swears in the word form, 3 swears in phrase form, and 5 swears in clause form. The results of the data classification showed that swearing in Bengkulu-Malay language tend to use the clauses form. The whole form of swear was in table 2 as below.

Table 2 The Swear Form of Banter Context in Bengkulu-Malay Language

\begin{tabular}{cccc}
\hline NO & The Swear Form & Swear Data & Meaning \\
\hline 1 & Word & (1) bundung & the disease of neck swelling in cattle \\
& & (2) buyan & Stupid \\
2 & Phrase & (6) ikan buntal & Puffer fish \\
& & (9) tino bunting & you are fucking sissy \\
3 & Clause & (4) palak kau & Pregnant woman \\
& & (3) cuk bak kau & your fucking father is having sex \\
& & (5) keparat sgalo toboko & you're all fucking infidel \\
& (8) palak bak kau & your father fucking head \\
& (10) matilah cepek kau & you will die soon
\end{tabular}

The clause is a minimal element of discourse. The clause consists of two or more elements and one of the elements is predicative. This shows that the essence of the clause is a predicate. There were 5 swear data in form of clause with a banter context, they were: (3) cuk bak kau 'your fucking father is having sex', (4) palak kau 'your fucking damn head', (5) keparat sgalo toboko 'you're all fucking infidel', (8) palak bak kau 'your father fucking head', and (10) matilah cepek kau 'you will die soon'.

The form of the swear clause also showed the tendency to use the pronoun second-singular person "you" with a total data was 4. Kridalaksana [8] stated that pronouns are the categories whose function to replace nouns and are based on whether references are clear or not, including the definite pronouns, for example pronouns that replace nouns whose references are clear and are only limited to personal pronouns can be found on swear data as follows: (3) cuk bak kau 'your fucking father is having sex', (4) palak kau 'your fucking damn head', (8) palak bak kau 
'your father fucking head', and (10) matilah cepek kau 'you will die soon'. The entire data of swear clauses using the second singular personal pronouns were in table 3 as below:

Table 3 The Swear Clauses using Personal Pronouns in Bengkulu-Malay Language

\begin{tabular}{cccc}
\hline No & The Swear Form & Swear Data & Meaning \\
\hline 1 & Clause & (3) cuk bak kau & your fucking father is having sex \\
& & (4) palak kau & your fucking damn head \\
& & (8) palak bak kau & your father fucking head \\
& & (10) matilah cepek kau & you will die soon \\
\hline
\end{tabular}

According to Djajasudarma [3] the use of the personal pronoun 'you' can only be used among the participants who are already familiar with or are used by people of higher social status to greet friends of lower social status, or among people with same social status.

Based on this concept, the use of the second-singular pronoun 'you' in swearing of Bengkulu-Malay clause showed the indications that participants who used swear in a humorous context are familiar or used by people with the same social status and no or reduced social distance makes the speaker can speak impolitely.

The degree of respect that exists in a particular word situation is largely dependent on a number of relatively permanent factors, those are status or position, age, degree of intimacy, and so on. The opinion that points to the ranking of social relations between the speakers and the hearers involved in a conversation. According to Leech [4], there is a low value on the scale of power and the social distance. The concept as explained further is that if the relationship gets closer, the need for politeness will decrease and based on the findings of banter that is in order to make joke in Bengkulu-Malay language in the form of clause can be seen as follows:

(3). O1: 'Cuk bak kau!'.

Sanggama-bapak-kau

'Your fucking father is having sex!'.

Context: The use of swear in clause (3) is "Cuk bak kau!" "Your fucking father is having sex' was told by participant O1. O1 participant is a boy at the age of 15 years old and $\mathrm{O} 2$ participant is a boy at the age of 10 years old. The two participants were best friends. The swearing occured when $\mathrm{O} 1$ participant lost in playing the game and then he yelled angrily. $\mathrm{O} 2$ participant responded to the anger of $\mathrm{O} 1$ participant by laughing tauntingly that $\mathrm{O} 1$ participant was not yet proficient in playing games.

$$
\begin{aligned}
& \text { (4). O1: 'Palak kau!'. } \\
& \text { Kepala-kau } \\
& \text { 'your fucking damn head!. }
\end{aligned}
$$

Context: The use of swear in the form of clause (4) 'Palak kau! 'your fucking damn head!' was told by participant O1. The four participants were men as close friends. The swear occurred when $\mathrm{O} 3$ participant asked the three participants about their plans to go home from school. The hot weather made participants $\mathrm{O} 2$ and $\mathrm{O} 4$ would go home while participants $\mathrm{O} 1$ would go with his brother. $\mathrm{O} 3$ participant persuaded $\mathrm{O} 1$ participant not to go home by asking $\mathrm{O} 1$ participant to be lazy to join so that $\mathrm{O} 1$ participant laughed at them.

(8). O1: “'Palak bak kau!'.

Kepala bapak kau 'your father fucking head!'.

Context: The use of swear in a form of clause (8) "Palak bak kau! 'your father fucking head' was told by participant O1. Participants were O1 (14 years old boy) and O2 (11 years old boy). Both participants were close friends. Swearing occured when O1 participant played the 
game and $\mathrm{O} 2$ participant arrived. Seeing the $\mathrm{O} 1$ participant lost the game, participant $\mathrm{O} 2$ laughed and swore and drove to the home of $\mathrm{O} 2$ participant.

(10). O1: 'matilah cepek kau!'.

mati-segera-kau

'you will die soon!'.

Context: Using the swear clause (35) matilah cepek kau! 'you will die soon!' were told by participant $\mathrm{O} 1 . \mathrm{O} 1$ participant is a boy at the age of 9 years old and $\mathrm{O} 2$ participant is a boy at the age of 11 years old. Both participants are close friends. The swear occured when participant $\mathrm{O} 1$ saw participant $\mathrm{O} 2$ was buying candy at a food stall and asked for a treat. $\mathrm{O} 2$ participant laughed while rejecting the request. It made $\mathrm{O} 1$ participants condemning to the $\mathrm{O} 2$ participants.

\section{Conclusion}

The use of swear in addition to as a mean of expressing negative intentions (anger, frustration, disappointment, resentment, and humiliation), it is also used in a positive intentions with the context as a banter or a joke. Swear with the intention of a banter is a way to offend to be friendly (mock-impoliteness) with the principle: "to show solidarity with $t$, say something to $\mathrm{t}$ which is (i) clearly not true, and (ii) clearly not polite".

There were 10 swear data in Bengkulu-Malay language found, based on its lingual form, there were: 2 swear in a form of words, 3 swear in a form of phrases, and 5 swear in a form of clauses. The results of the data classification showed that the use of swear in a context of banter tended to use clause forms based on the social distance that both the speakers and hearers were having the indicators of the same degree of familiarity, status or position, and age.

\section{References}

[1] M. Ljung, Swearing (A Cross Cultural Linguistic Study). New York: Palgrave Macmillan, 2011.

[2] Vingerhouts, Swearing: a Biopsychocial Prespective. Psychological Topics, 2013.

[3] F. Djajasudarma, Metode Linguistik (Ancangan Metode Penelitian dan Kajian). Bandung: PT.Eresco, 1993.

[4] G. Leech, Prinsip-prinsip Pragmatik Diterjemahkan oleh. M.D.D.OKa.The Principle Of Pragmatics. Jakarta, 1993.

[5] I. D. P. Wijana and M. Rohmadi, Makian dalam Bahasa Indonesia: Studi tentang Bentuk dan Referensinya. Yogyakarta: Pustaka Pelajar, 2011.

[6] J. Holmes, An Introduction to Sociolinguistics. USA: Published Routledg, 2013.

[7] J. Rakhmat, Psikologi Komunikasi. Bandung: PT. Remaja Rosdakarya, 2003.

[8] H. Kridalaksana, Kamus Linguistik. Jakarta: Gramedia Pustaka Utama, 2008. 